\title{
NARASI CINTA DAN KEINDAHAN DALAM BAHASA SUFI IBN ARABI
}

\begin{abstract}
Ahmad Kholil
Dosen Jurusan Bahasa dan Sastra Arab,

Fakultas Humaniora dan Budaya, Universitas Islam Negeri (UIN) Malang.

Jalan Gajayana No. 50 Telepon (0341) 570872, Faksimile (0341) 570872 Malang 65144
\end{abstract}

\begin{abstract}
Ibn Arabi is the type of the mystical-muslim philosophy. He was known as the founder of an idea "wahdat al-wujud", and his theory explained that cosmos was created by God from its one-necleus. So, in spite of its external aspects different and has variations, its essence just one. It mind there is God attribut in cosmos, and God is the essence of its share. The common of mystical muslim coveted the "kasyf" to understand Him, The Great Unity, God. In this case, Ibn Arabi connected it and love. Love, Ibn Arabi said, had to come into existence becaose of "jamal", the beaty which God-loved and "ihsan", the beautiful attitude to reach love of God.
\end{abstract}

\section{Key words}

Naration, Mystical, Ibn Arabi

\section{Pendahuluan}

Muhyiddin ibn Arabi, yang dikenal dengan al-Syaikh al-Akbar (Maha Guru) adalah seorang jenius yang unik di dunia ajaran mistik. Ia lahir di Murcia, Spanyol Muslim 1165 M. dan wafat di Damaskus 1240 M. Ibn Arabi telah dihormati oleh para mistikus sufi sejajk ia menghebohkan dunia Islam pada peralihan abad ketiga belas. Ia mewariskan lebih dari 350 buku dan risalah, karya-karya bermutu 
tinggi yang layak disebut sebagai karya klasik dalam spiritualitas dunia modern (Hirtenstein, 2001: 6).

Karyanya al-Futuhat al-Makiyyah yang mencapai ratusan halaman memancarkan cahaya atau kilauan dari ilmu-ilmu cahaya yang ia peroleh ketika "Tuhan" membukakan baginya pintu-pintu menuju "perbendaharaan pengetahuan batini" (treasures of unseen generousity). Fushus al-Hikam (mutiara-mutiara cincin kebijakan) merupakan ringkasan ajaran-ajarannya yang mensintesakan hukum syari'at (fiqh), teologi, filsafat, tasawuf, kosmologi, psikologi, dan ilmuilmu keislaman lalinnya.

Signifikansi pengaruh Ibn Arabi terhadap pemikiran Islam didasarkan pada kisah pertemuannya sebagai seorang pemuda yang baru menginjak usia 16 -an tahun dengan filosof terkenal Avverus (Ibn Rusyd) yang saat itu telah berumur 55 tahun. Ibn Rusyd melihat dalam diri Ibn Arabi muda terkandung kebijaksanaan yang selama ini ia cari. Dengan bahasa yang samar anak muda itu telah memberitahukan pengertian kepadanya bahwa penyellidikan rasional belumlah memadai untuk menggapai pengetahuan sempurna tentang Tuhan dan alam semesta (Corbin, 1969: 41).

Kejeniusan Ibn Arabi terletak pada penyingkapan dalam arena kesatuan kosmos dan yang berdasarkan petunjuk Ilahi. Wawasannya tentang human experience sangat luas dan menyeluruh (komprehensiph). Ia mendeskripsikan pemikiran sebagai "tamu dari langit yang melintasi ladang hati" di mana hati tersebut menggambarkan landasan paling dalam dari kesadaran manusia (Hussen, 1964: 4). Dalam pengertian ini pemikiran tidak hanya mengacu pada proses otak, atau sesuatu yang dapat dipikirkan, atau direnungkan, tetapi mengindikasikan sesuatu yang dapat muncul setiap saat di dalam diri, di dalam kesadaran diri manusia.

Ibn Arabi membagi pemikiran menjadi pemikiran yang positif dan bermanfaat, dan pemikiran yang negatif dan sia-sia. Masing-masing tamu ini memerlukan eksistensi seseorang untuk mengolah lalu 
membawanya ke sebuah tempat di mana mereka nanti dapat mewujud dan eksis dalam tatanan sosial yang praktis.

Pada sajian ini penulis hanya akan mengetengahkan hasil eksplorasi terhadap sebagian kecil karya-karya Ibn Arabi secara deskriptif tanpa analisis njlimet menghubungkan teori ini dan itu. Demikian juga sajian ini tidak dimaksudkan untuk menunjukkan seberapa ortodoks ajaranya tentang Islam. Pembahasan semakin tampak sederhana karena hanya dibatasi pada persoalan inti kemanusiaan tentang cinta dan keindahan.

Tulisan ini bermaksud untuk menyampaikan sesuatu dari "aroma Ibn Arabi", yaitu suatu pemahaman akan kebesaran dan kejeniusannya terkait dengan humanisme -yang penulis pahami.

\section{Sekilas Biografi Ibn Arabi}

Dia adalah Abu Abdillah Muhyiddin Muhammad ibn Ali ibn Muhammad ibn al-Arabi al-Hatimi, lahir Senin pada 17 Ramadhan 560 H. atau 27 Juli 1165 M. di kota Murcia, Andalus, Spanyol. Lahir sebagai anak pertama dari tiga bersaudara dan ia satu-satunya yang laki-laki. Tujuh tahun pertama kehidupan Ibn Arabi tampaknya dihabiskan di tengah-tengah konflik dan ketegangan sosial. Ayah Ibn Arabi adalah anggota kelompok tentara pengawal pribadi sultan dari dinasti Almohad (al-Muwahidin). Posisi ini merupakan kedudukan prestisius dan kuat, yang memberinya akses kepada semua orang yang memiliki pengaruh besar, seperti filosof dan hakim terkenal dari Kordoba Ibn Rusyd. Meskipun bukan dari keluarga aristokrat, Ibn Arabi tampaknya lahir dari keluarga yang beruntung.

Jalur yang terkakit langsung dengan pedahulunya yang termasyhur adalah Hatim dari suku Toyy, suku Arab penting dari Yaman. Hatim al-To'i adalah penyair pra-Islam yang hidup paruh kedua abad keenam masehi dan diakui secara luas sebaai contoh terbagus dari kesatriaan di dunia Arab sebelum datangnya Nabi Muhammad. Lebih dari itu, nama Hatim bahkan menjadi pameo untuk kejujuran dan keluhuran budi. Tidak diragukan, teladan ketidak- 
egoisan dan kemurahan hati ini dipegang teguh oleh keluarga Ibn Arabi.

Pada tahun 1172 M. karena peralihan kekuasaan, ayah Ibn Arabi bersama keluarganya pindah ke Sevilla, pusat kosmopolit yang ramai dan makmur, dan menjadi ibu kota kerajaan Almohad di Spanyol. Kota ini menjadi titik temu antar berbagai ras dan kultur, di mana penyanyi dan penyair kumpul dan dialog dengan filosof dan teolog, dan para wali berdampingan dengan para pendosa. Jadi, sejak usia 7 tahunan Ibn Arabi tumbuh di lingkungan yang penuh dengan ide-ide penting pada masa itu -ilmu pengetahuan, agama, dan filsafat.

Sebagian besar dari kehidupan awalnya dihabiskan seperti lazimnya anak-anak muda yang baru tumbuh. Pendidikannya adalah pendidikan standar untuk keluarga muslim yang baik. Dia belajar alQur'an pada salah seorang tetangganya, ibn Abdillah Muhammad alKhayyat, yang kemudian sangat ia cintai dan tetap menjadi sahabat dekatnya selama bertahun-tahun. Ibn Arabi muda tampaknya adalah seorang yang suka berburu, dan peristiwa berikut mengungkapkan sensivitas dan kebijaksanaannya :

"Suatu ketika, pada masa kejahiliaanku (sebelum pencerahan spiritualnya), aku dalam perjalanan bersama ayahku dikawal beberapa personil tentara. Aku melihat sekawanan keledai liar sedang merumput, dan pembantuku berada cukup jauh dariku. Aku berpikir lalu memutusakan dalam hati bahwa aku semestinya tidak boleh melukai salah satu dari mereka dengan memburunya. Ketika kuda yang kutunggangi melihat mereka dan berlari ke sana, aku mengendalikannya dan sampailah aku ke sana dan bergerak di tengah mereka. Ujung tombak yang aku pegang bisa saja menusuk salah satu punggung dari hewan itu, tetapi demi Allah, hewanhewan itu bahkan tidak mengangkat kepalanya sedikitpun. Kemudian para pengawal melihatku, dan saat mereka tiba, keledaikeledai itu berlarian. Aku tidak tahu bagaimana menjelaskan hal ini, sampai aku kembali ke jalan (spiritual), yaitu jalan Allah. 
Kemudian melalui pengamatan interaksi sosial, aku mengetahui penyebabnya, yaitu perasaan ketenangan dan keamanan yang kurasakan terhadap mereka (hewan-hewan itu) telah mengkomunikasikan dirinya sendiri."

Tampaknya Ibn Arabi muda diharapkan untuk mengikuti jejak ayahnya, bertugas dalam pasukan tentara sultan selama beberapa waktu, dan juga dijanjikan kedudukan sebagai asisten gubernur Sevilla. Dia sendiri menyebut periode kehidupan ini periode jahiliyyah. Jahiliyyah Ibn Arabi ini bukanlah masa ketika ia melakukan maksiat atau tindakan yang kurang terpuji, melainkan hanya ketidak peduliannya terhadap Tuhan dan terbujuk oleh daya tarik duniawi.

Sejak tahun 620 H./1223 M. Ibn Arabi tinggal di Damaskus, di mana dia dengan sejumlah murid-muridnya tetap tinggal di sana hingga akhir hayat. Dia memanfaatkan waktunya untuk belajar, menulis dan mengajar. Pada saat yang bersamaan dia juga melibatkan diri dalam kehidupan sosial-politik di tengah-tengah masyarakatnya dan menjalin hubungan baik dengan setidaknya, tiga raja lokal. Salah seorang dari mereka mendapat perhatian khusus dalam tulisan-tulisannya. Dalam sebuah dokumen yang ditulis tahun 632 H./1240 M. dia meminta idzin kepada Ayyubid Mudzaffar al-Din Musa (memerintah di Damaskus antara tahun 627-632 H.) untuk mengajarkan seluruh ajarannya yang ia tuangkan dalam 290 tulisan. Dalam dokumen tersebut dia menyebutkan 99 nama gurunya.

Kapan dia meninggal? Untuk menjawab pertanyaan ini tidak ada sumber yang menyebutkan dengan jelas. Namun ada yang mengatakan bahwa Ibn Arabi suatu hari sedang berjalan di tengah kerumunan massa yang sedang menghadiri "halaqah", tiba-tiba ada yang bertanya padanya,"Di manakah Tuhan berada?" Dengan tenang dia menjawab, "Tuhan kalian berada di bawah kakiku." Sontak massa meneror Ibn Arabi dan konon, teror itu salah satu penyebab meninggalnya Ibn Arabi. 
Setelah beberapa lama, di bekas Ibn Arabi berdiri ada penggalian dan ditemukanlah di situ emas-emas yang menjadi incaran banyak orang. Maka menjadi jelaslah kini kebenaran yang dikatakan Ibn Arabi.

\section{Sufisme Ibn Arabi}

Berikut kutipan terjemahan bait syair Ibn Arabi:

"Sungguh hatiku telah menerima segala bentuk

Ia bagai padang rumput bagi sekawanan rusa

Biara bagi rahib-rahib kristen

Kuil bagi penyembah berhala, Ka'bah bagi peziarah

Hatiku adalah lembaran Taurat dan kitab al-Qur'an

Kuanut agama cinta, jalan yang ditempuh onta-onta cinta

Cinta adalah agama dan jalan (keyakinan)-ku"

Bait syair tersebut dihadirkan di sini karena sesuai sekali dengan jalan pikiran Ibn Arabi tentang humanisme dan -lebih spiksifik dan trend saat ini- kesatuan agama-agama (the unity of religions). Ini mengingatkan kita pada sebuah teori emanasi dalam filsafat; segala rupa muncul dari Yang Satu, tetap Satu dan akan kembali pada Yang Satu. Agama pada dasarnya juga satu, kepunyaan Allah Yang Maha Satu, apapun wadah dan namanya. Manusia mempunyai kepercayaan yang berbeda-beda tentang Tuhan, namun mereka mempunyai keyakinan yang sama "Tuhan itu ada".

Ibn Arabi, sepanjang pada persoalan yang dibahas tentang ketasawufannya dalam tulisan ini, konsisten mengembalikan segala hal pada satu tema dasar "segala sesuatu saling berhubungan melalui akar kesamaan dalam realitas ketuhanan". Keanekaragaman alam semesta yang tak terbatas, tidak lain adalah manifestasi lahir belaka dari namanama Tuhan, dan wajah Tuhan tercermin pada segala ciptaan-Nya. Nama-nama Tuhan dalam wahyu bagi Ibn Arabi menjadi kunci untuk 
pintu yang akan membukakannya pada dunia yang tidak nampak oleh mata lahir (Hamid, 2004: 209).

Agama -dalam hal ini juga sufisme-, memang persoalan batin, i'tikad dan olah rasa/emosi, oleh karena itu sangat mementingkan kemampuan memenej jiwa, dan substansi agama memang terletak di wilayah itu. Sungguhpun tempat di mana keyakinan bersemayam bukan pada nalar-intelektual, akan tetapi agama juga mengajak para pengikutnya untuk menggunakan (mengolah ) akal, dan hanya orangorang yang berakal sajalah yang (sempurna-dalam) beragama (Hamid, 2004: 209).

Dalam pandangan Ibn Arabi, ada tiga mode validitas dasar untuk memperoleh pengetahuan; penyelidikan rasional, wahyu kenabian, dan penyingkapan (kasyf) atau pembukaan pengetahuan untuk menuju pengetahuan Tuhan. Dalam konteks dua model pertama, dia mengikuti aturan yang dirumuskan oleh para ahli yang relevan dalam ilmu pengetahuan tersebut, seperti logika dan yurisprudensi (ushul al-fiqh), dan dia secara jelas memisahkan antara yang sesaui dengan ketentuan-ketentuan yang rasional dan yang tidak, antara yang benar menurut aturan yurisprudensi ataupun yang tidak. Pada saat yang sama, di dalam perspektif mode pengetahuan ketiga, dia menerima keabsahan setiap perspektif yang ada. Karena itu, dalam Futuhat, seperti dikutip William C. dia menulis:

"Agama wahyu mempunyai kekuasaan di mana realitas yang tidak mengikutinya akan terperosok, hanya kemampuan nalarlah yang mempunyai kekuasaan semacam itu. Saya hidup di saat ini, dengan nalar saya menolak apa yang ditolak akal, dan kemudian sejak itu kehadiran saya adalah akal. Namun saya bisa menolaknya dengan penyingkapan (kasyf) atau dengan wahyu. Dengan agama wahyu saya menolak apa yang ditolak agama tersebut, sejak itu kehadiran saya adalah agama wahyu. Saya tidak bisa menolaknya dengan kasyf atau nalar. Berkenaan dengan penyingkapan, akal 
tak menolak apapun. Sebaliknya dia meneguhkan segala sesuatu menuju tingkat yang lebih baik. (William C, 2001: 27)

Di dalam naskah-naskah klasik ataupun modern Ibn Arabi sangat sering dikenal sebagai pencetus pertama doktrin wahdat al-wujud "kesatuan wujud atau kesatuan eksistensi". Namun ekspresi ini tidak ditemukan dalam karya-karyanya. Kalaupun al-Syaikh al-Akbar ini tidak pernah mengekspresikan wahdat al-wujud, dia seringkali membuat pernyataan-pernyataan yang semakna dengannya, karena itu, sah saja bila diklaim bahwa dia mendukung ide wahdat al-wujud (Chittick, 2001: 27).

Diantara bait-bait puisi yang mendeskripsikan aspek tasawwuf Ibn Arabi seperti berikut ini (Ibn Arabi, 1964: 83):

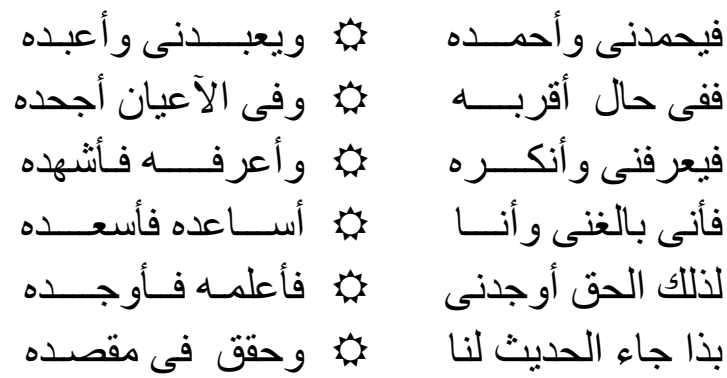

"Maka Ia memujiku aku memuji-Nya, dan Ia menyembahku akupun menyembah-Nya

Dalam hal (lahir) aku mengakui-nya, dan dalam hal lain (hakiki) aku menolaknya

Maka Ia mengenalku aku tak mengenal-Nya, lalu aku mengenalNya akupun menyaksikannya

Maka bagaimana mungkin Ia bisa cukup, padahal aku menolong dan membahagiakan-Nya

Untuk itulah al-Haqq mewujudkan aku, maka akupun mengetahui dan mewujudkan-Nya 
Demikianlah, sebuah perisiwa datang pada kita dan di dalam diriku terealisasi tujuan-Nya"

Bila bait puisi di atas dipahami secara literal, kesimpulan yang diperoleh ialah bahwa Ibn Arabi telah mengabaikan arti ketuhanan, ia telah memperlakukakan Tuhan setara dengan dirinya (makhluk), hingga ia dihukumi kafir karena dianggap menghina Tuhan. Akan tetapi, bila hal ini dikembalikan pada doktrin wahdat al-wujudnya, yang merupakan landasan bertolaknya dalam memandang segala sesuatu, maka apa yang diucapkan adalah benar-benar saja.

Sekalipun Syaikh menggunakan kata wujud dalam pengertian yang beragam, ia memahami istilah tersebut dengan satu pengertian fundamental, kemudian menyajikan fakta bahwa wujud adalah satu. Perbedaan pengertian pada saat istilah tersebut digunakan harus dapat dipahami dengan mengandaikan perbedaan realitas tunggal dari pemahaman wujud itu sendiri. Pada tingkat tertinggi, wujud adalah realitas Tuhan yang absolut dan tak terbatas, yakni "Wujud Niscaya" (wajib al-wujud ). Dalam pengertian ini, wujud menandakan esensi Tuhan atau al-Haq, satu-satunya realitas yang wujudnya ada di setiap sisi. Sedang pada tingkat terbawah, wujud berupa substansi yang meliputi segala sesuatu selain Tuhan (ma siwa Allah). Dengan cara inilah Ibn Arabi mendefinisikan kosmos atau jagad raya denan konsep wahdat al-wujud nya (Hamid, 2004: 185-186).

Wal-hasil, menisbatkan asal doktrin wahdat al-wujud kepada Ibn Arabi tidaklah salah, karena dia menegaskan bahwa wujud dalam pengertian yang sebenarnya adalah realitas tunggal dan tidak dapat menjadi dua wujud. Dalam hal ini, ungkapan tauhid "tidak ada tuhan (tkecil) selain Tuhan (T-besar)" berarti "tidak ada wujud selain Tuhan (Allah)". Namun demikian, ia menekankan untuk menjelaskan realitas jamak (katsroh) di dalam konteks kesatuan Tuhan.

Dalam pandangan Ibn Arabi keragaman nyaris tampak tunggal ketika ia juga berakar dari Tuhan (al-Haqq), sebagai wujud yang tunggal dan satu-satunya eksistensi yang sejati. Kalau boleh dianalogkan 
dengan cahaya yang memancarkan aneka warna, dapat ditegaskan tentang hakikat warna tersebut, tanpa klaim bahwa setiap warna adalah sesuatu yang ada dengan sendirinya. Merah, hijau, ataupun apa dalam pancaran cahaya itu hanya ada melalui sinarnya, masing-masing merupakan satu dalam substansi kilauannya, namun beragam dalam realitas kekhasannya.

\section{Tentang Cinta dan Keindahan}

Adalah Rabi'ah al-Adawiyah (w. 185 H./801 M.) sufi yang mengilustrasikan ibadah yang dilakukan oleh seorang hamba dengan dasar ketakutan atas siksa dan "ketamakan" pada pahala sebagai hamba yang menyusuri jejak orang-orang yang kurang terpuji, dia akan patuh dan taat ketika dalam keadaan susah. Sebaliknya, suloyo dan ingkar ketika sudah mendapatkan kenikmatan kebahagiaan. Adapun ibadah yang dibangun atas dasar cinta, menurut Rabi'ah Adawiyah itulah yang terpuji (benar) dan si abid dengan cintanya akan sampai pada eksistensi (rido) yang dicinta, serta akan tersingkap baginya "kegelapan" sehingga tampaklah olehnya segala sesuatu -realitas fisik indrawi dan batiniseperti adanya. Rabi'ah berkata:

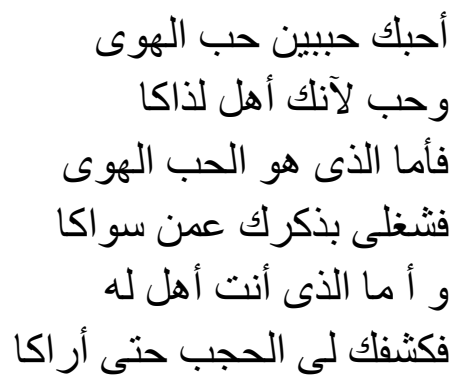

Ketika tabir sudah tersingkap, ego keakuan seorang sufi menghilang menuju ke kesatuan Yang Maha Tunggal "Al-Wahid". Kondisi demikian ini dalam persepektif tasawuf disebut ekstase (alsyathahat). Ada juga yang menyebutnya dengan istilah hulul atau 
ittihad, seperti yang dialami Hussen ibn Manshur al-Hallaj (w. 309 H./920 M.) dengan mengatakan (Hamid, 2004: 76):

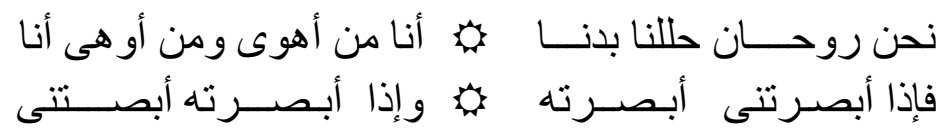

"Aku orang yang merindu, dan orang yang merindu adalah aku

Aku dua roh menempati satu badan

Bila engkau melihatku, engkau juga melihat Dia

Bila engkau melihat Dia, engkau juga melihatku"

Dalam kondisi ekstase, seperti yang dialami al-Hallaj di atas, ia terbawa pada ucapan-ucapan yang subyektif. Bahkan mungkin telah menjadi kebiasaan di kalangan para sufi ketika berada dalam situasi tersebut mereka hanya mengemukakan perasaan yang dialami dirinya sendiri. Artinya mereka kehilangan kontrol dan akalnya sudah tidah mampu menguasai emosinya.

Kembali pada persoalan cinta, dalam salah satu karyanya, sang Syaikh menerangkan adanya hubungan timbal balik antara cinta Tuhan dengan cinta makhluk-Nya melalui term penglihatan ( $\left.r u^{\prime} y a h\right)$ dan pendengaran (sama'). Cinta Tuhan kepada makhluk-makhluk-Nya bermuara pada penglihatan terhadap mereka di dalam diri-Nya sendiri, di mana mereka identik dengan diri-Nya. Dia melihat mereka melalui "perbendaharaan yang tersembunyi" (kanzan makhfiyan), sehingga Dia ingin dikenal. Cinta makhluk terhadap Khaliq-Nya berasal dari pendengaran akan firman "jadilah" yang kemudian menjadikan mereka terwujud.

Lebih lanjut ia mengatakan, "Sebagaimana cinta kita kepadaNya, asalnya adalah 'pendengaran' bukan 'penglihatan'. Ia adalah firman-Nya kepada kita-sementara kita berada dalam substansi awan"jadilah". Dalam hal ini, awan berasal dari nafas-Nya, sementara bentuk-bentuk yang disebut kosmos berasal dari firman-Nya "jadilah", 
karenanya kita adalah firman-Nya yang tidak tertulis. Ketika kita mendengar firman-Nya, sementara kita berada dalam substansi awan, kita tidak bisa menarik diri dari eksistensi. Kita menjadi bentuk-bentuk yang berada di dalam substansi awan. Melalui pengejawantahan kita di dalam awan, Dia memberi kita wujud awan. Sesuatu yang mewujud berarti telah memperoleh wujud. Inilah asal dari cinta kita kepada "Tuhan" (Chittick, 2001: 353).

Karakter cinta selalu egois dan berorientasi diri, namun ini tergantung diri macam apa yang dimaksud. Jika perasaan cinta yang ada pada seseorang ditujukan untuk Tuhan, sebetulnya dia mencintai Tuhan itu adalah demi kegembiraan dan kebahagiaan yang dirasakannya sendiri. Demikian juga jika cintanya untuk seseorang, cinta tersebut adalah demi kegembiraan dan kebahagiaannya sendiri. Namun demikian, hal seperti ini bukanlah suatu kesalahan, karena cinta alamiah senacam ini sepenuhnya pembawaan manusiawi.

Pengetahuan tentang makna cinta semacam ini yang menandai posisi umumnya manusia, dan menjadi awal dari cinta spiritual. Mencintai adalah melupakan semua yang lain, menutup mata dan telinga untuk semua hal selain kepada yang dicinta, "kekasih". Pada titik tertentu cinta akan tergiring pada kesadaran bahwa kekasih sebenarnya yanng dicinta adalah Dzat yang menampakkan diri di dalam bentuk namun secara paradoks sekaligus disembunyikan oleh bentuk. Membayangkan bahwa "kekasih" sejati maujud dalam satu bentuk tidak lain adalah sejenis orang mabuk yang tersesat dan tak tahu arah.

Tentang kekasih sejati ini, Ibn Arabi (Turjumal Aswaq: 39) mengatakan:
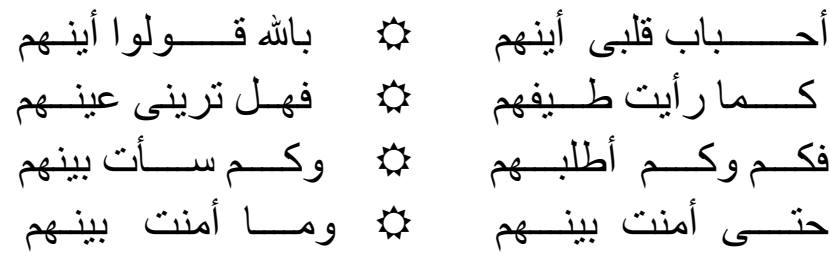


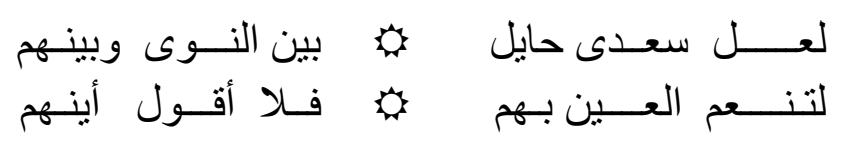

Kekasih hati, katakan di mana mereka

Kau tahu pengembaraannya, mengapa tak kau tunjukkan kebaraberadaannya

Betapa aku telah mencari-cari, dan meminta selalu bersama mereka Hingga karena takut berpisah, kini aku gelisah di tengah mereka Tapi mungkin kebahagiaanku memang terpendam, di tengah jagad raya dan kekasih itu

Maka kini diri ini merasa bahagia, dan tak lagi bertanya di mana mereka

Dalam penyingkapan untuk mengetahui Dia Sang "Kekasih" kepada hati, para sufi menghubungkannya dengan dua nama Ilahi yang menurut Ibn Arabi merupakan penyebab cinta ; sifat keindahan (jamal) dan keindahan dalam amal (ihsan). Yang disebut belakangan ini, seperti dijelaskan William C. menganndung semua jenis resonansinya dalam bahasa Arab : amal yang baik atau benar, kemurahan hati, kecantikan, kebaikan. Kata itu juga mengandung dua konotasi khusus dari akar yang sama terhadap kata husna yang berarti paling indah, dan merupakan julukan dari nama-nama Ilahi, nama-nama yang paling indah ( al-Asma' al-Husna). Kedua mengacu kepada dialog yang terjadi antara Nabi Muhammad dengan Jibril. Ketika Jibril meminta Nabi untuk mendefinisikan ihsan, Ia menjawab:

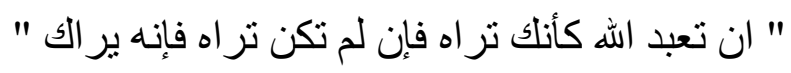

Jadi ihsan atau amal yang baik atau indah adalah menyembah Allah seolah-olah melihat-Nya, yaitu melihat kualitas positif dalam setiap perwujudan. (Chittick, 2001:264) 
"Penyebab cinta adalah keindahan (jamal) yang merupakan milik-Nya, dan keindahan dicintai karena diri-Nya sendiri, "Allah itu Maha Indah dan mencintai keindahan". Jadi, Dia mencintai Diri-Nya sendiri dan penyebabnya adalah tindakan memperindah (ihsan). Tidak ada tindakan memperindah kecuali dari Allah, dan tidak ada yang menjadikan indah kecuali Allah. Maka, ketika aku mencintai karena tindakan keindahan, aku hanya mencintai Allah semata, karena Dia adalah yang menciptakan keindahan (muhsin), dan ketika aku mencintai keindahan, aku tak mencintai satupun kecuali Allah, karena Dia Yang Maha Indah (jamil). Jadi di dalam setiap aspek, cinta selalu dihubungkan hanya dengan Allah.

Dalam hubungannya dengan agama, sebagai bentuk formal keyakinan umat, dan seringkali menjadi spirit utama tindak kemanusiaan yang dihubungkan dengan ketuhanan, Ibn Arabi mengajarkan :

"My heart has become capable of every form : it is a pasture for gazelles and a convent for christian monks,

And a temple for idols and the pilgrim's Ka'ba and the tables of the Tora and the book of the Koran,

I follow the religion of love: whatever way love's camels take, that is my religion and my faith".

\section{Penutup}

Ibn Arabi secara tipikal dianggap sebagai seorang sufi-falsafi, anggapan ini relatif benar jika dipahami istilah sufisme-falsafi yang ditekankan pada pemikiran teoritis dan praktek keagamaan yang menekankan pada pengalaman spiritual langsung dari obyek-obyek iman. Seperti para penganut tasawuf lainnya, ia juga sering dikutip sebagai pendukung ide "the unity of religion" di mana agama dipahami tidak hanya sebagai bentuk, tapi secara hakiki "kepasrahan" total yang titik tolaknya dari sebuah keyakinan di dalam hati. Oleh 
karena itu, kaum sufi umumnya memiliki sikap toleran dan sangat mengagumkan terhadap praktek-praktek keagamaan yang sepintas bertentangan dengan pakem -syari'ah- (fiqh) dibanding dengan kaum non sufi.

Nisbah tasawuf-falsafi kepada Ibn Arabi juga karena tulisantulisannya kaya dengan pemikiran filsafat. Pemikiran tersebut antara lain tentang proses keyakinan kegamaan yang hubungannya dengan wahyu, pemikiran rasional, dan imajinasi, tentang kosmos dengan kemungkinan kebersatuannya dengan "al-Haqq", manusia bisa "manunggal" dengan Allah karena adanya kesamaan esensi antara keduanya.

Sudah menjadi tradisi kaum sufi, memandang keberagamaan ataupun sikap-sikap fisik-dhahiriyah pada akar penggeraknya yaitu batin. Secara sederhana, bahasan pada tulisan ini adalah kupasan tentang rasa cinta dan keindahan yang melahirkan penghormatan terhadap segala entitas yang ada di jagad. Kaum sufi memberi penekanan lebih besar pada kualitas-kualitas tertentu yang mempererat ikatan antara pecinta dan yang dicinta. Cinta itu sendiri, menurut pandangan Ibn Arabi disebabkan oleh dua hal ; "jamal” keindahan yang dicintai Tuhan, dan "ihsan" keindahan sikap untuk meraih cinta Tuhan. Maka cinta akan terealisir dalam kosmologi insani pada sikap-sikap yang elok dan mengagumkan. $\nabla$ 


\section{DAFTAR PUSTAKA}

Basaj. Hasan. 1990. Diwan Ibn Arabi. Beirut: Dar al-Kutub al-Ilmiyah.

Chittick, William C. 2001. Tuhan Sejati dan Tuhan-tuhan Palsu, terj. Achmad Nidjam dkk. Yogyakarta: Qalam.

--------. 2001. Dunia Imajinal Ibn Arabi: Kreativitas Imajinasi dan persoalan Diversitas Agama, Terj. Achmad Syahid. Surabaya: Risalah Gusti.

Corbin, Henry. 1969. Creatif Imagination in the Sufisme of Ibn Arabi. Princeton: Princeton Univercity Press.

Hamid, Nashr Abu Zaid. 2004. Hakadza Takallama Ibn Arabi. Al-Maghribi: Dar a-Baidla'i.

Hirtenstein, Stephen. 2001. Dari Keraguan ke Kesatuan Wujud; Ajaran dan Kehidupan Spiritual Syaikh al-Akbar Ibn Arabi. Jakarta: Raja Grafindo Persada.

Hussen, Sayyed Nasr. 1964. Three Muslim Sages. Cambridge: Cambridge University Press.

Ibn Arabi, Muhyiddin. 1978. The Turjuman al-Aswaq, by Reynold A. Nicholson. London: Theosophichal Publishing House.

--------. 1964. Fushush al-Hikam. Abu al-A'la Afifi (Ed). Kairo: Dar Ihya al-Kutub al-Arabiyah.

--------. 1968. Dakha'ir al-A'laq. Muhammad Abdirrahman al-Kurdi (Ed). Kairo: Tanpa Penerbit

Rahman, Saleh. 2003. "Subyektivitas dalam Tasawuf; Konsepsi Ibn Arabi tentang Tuhan, Kosmos dan Penemuan Diri", dalam Al-Huda; Jurnal Ilmu-Ilmu Islam. Jakarta: Al-Huda. 